\title{
Regulation of ribulose bisphosphate carboxylase gene expression in natural phytoplankton communities. I. Diel rhythms
}

\author{
S. L. Pichard ${ }^{1}$, L. Campbell ${ }^{2}$, J. B. Kang ${ }^{1}$, F. R. Tabita ${ }^{3}$, J. H. Paul ${ }^{1, *}$ \\ 'Department of Marine Science, University of South Florida, St. Petersburg, Florida 33701, USA \\ ${ }^{2}$ Department of Oceanography, School of Ocean and Earth Science and Technology, University of Hawaii, Honolulu, \\ Hawaii 96822, USA \\ ${ }^{3}$ Department of Microbiology and the Plant Molecular Biology and Biotechnology Program, The Ohio State University, \\ Columbus, Ohio 43210, USA
}

\begin{abstract}
Marine phytoplankton fix carbon dioxide primarily through the action of ribulose-1,5-bisphosphate carboxylase/oxygenase (RubisCO), the first enzyme in the Calvin Cycle. Although the regulation of this enzyme has been studied in algal cultures and higher plants, little is known regarding RubisCO regulation in natural phytoplankton populations. To determine if natural communities of phytoplankton utilize transcriptional regulation to control Rubis $\mathrm{CO}$ expression, we investigated the diel relationship between ${ }^{14} \mathrm{C}$ carbon fixation and RubisCO large subunit $(r b c L$ ) transcript levels, $r b c L$ DNA, chlorophyll a, autofluorescent cell counts and bacterial direct counts for natural communities of the southeastern Gulf of Mexico. Studies were performed with natural phytoplankton populations in Lagrangian studies or deck-top incubators as well as with a Prochlorococcus isolate in culture from the North Pacific Ocean. $r b c L$ mRNA and DNA were detected by stringent hybridization using an antisense rbcL RNA gene probe originating from Synechococcus sp. PCC 6301. For natural communities, carbon fixation maxima ( 0.1 to $0.7 \mu \mathrm{g} \mathrm{C} \mathrm{l}^{-1} \mathrm{~h}^{-1}$ ) occurred from early morning to mid afternoon, with minimal values at night. Peak levels of rbcL mRNA ( 3.6 to $22.2 \mathrm{ng} \mathrm{l}^{-1}$ ) almost always coincided with the time of maximum carbon fixation and were positively correlated. When natural phytoplankton populations or the Prochlorococcus culture were maintained in continuous illumination for $24 \mathrm{~h}$, the same diel pattern of RubisCO regulation was observed, implying that diel entrained rhythms in $r b c L$ transcription occurred. The results thus indicate that natural phytoplankton communities appear to regulate carbon fixation at least in part by transcriptional control of RubisCO synthesis and that such patterns appear to be rhythmic in nature.
\end{abstract}

KEY WORDS: RubisCO mRNA Prochlorococcus. Synechococcus Natural phytoplankton

\section{INTRODUCTION}

The majority of oceanic carbon fixation results from the ability of phytoplankton to perform photosynthesis. Phytoplankton productivity is responsible for nearly $40 \%$ of the annual global conversion of inorganic carbon to organic carbon (Falkowski 1994). In phytoplankton the enzyme primarily responsible for $\mathrm{CO}_{2}$ fixation is ribulose-1,5-bisphosphate carboxylase/oxygenase (E.C. 4.1.1.39, RubisCO). The regulation of

-Addressee for correspondence.E-mail: jpaul@marine.usf.edu photosynthetic carbon fixation in response to time of day or diel changes in insolation in natural phytoplankton populations is poorly understood. We have become interested in understanding the regulation of this enzyme in an effort to elucidate factors affecting $\mathrm{CO}_{2}$ fixation in the oceans and on the continental shelves.

In almost all phytoplankton, certain phototrophic and chemoautotrophic bacteria, and aquatic and terrestrial vascular plants, RubisCO exists as a multisubunit protein comprised of 8 large and 8 small subunits $\left(L_{8} S_{8}\right)$. The large and small subunits are encoded 
by the $r b c L$ ( $c b b L$ ) and $r b c S(c b b S)$ genes, respectively In a previous study it has been shown that there is a direct relationship between the level of $r b c L$ mRNA and the carbon fixing ability of phytoplankton (Pichard et al. 1993). A linear relationship has also been observed for carbon fixation and RubisCO protein levels in Thalassiosira weissflogii (Orellana \& Perry 1992), although Rubis $\mathrm{CO}$ enzyme activity has not always been found to be as tightly coupled to maximum photosynthetic activity for natural communities (Glover \& Morris 1979).

Diel or diurnal variations in photosynthetic carbon metabolism have been observed both for natural phytoplankton communities in the field and in cultures of phytoplankton isolates (Doty \& Oguri 1957). Several field studies have shown that carbon fixation, photosynthetic capacity $\left(P_{\max }^{B}\right)$ and photosynthetic efficiency of natural communities change during the day with minimum values occurring during the night and maximum values occurring either before or after solar noon (Legendre et al. 1988). Eukaryotic phytoplankton (members of the Dinophyceae, Phaeophyceae, Bacillariophyceae, and Chlorophyta) have been shown to exhibit entrained rhythms in photosynthesis (Sweeney 1983). Diel rhythms in cell division, nifH and rbcL have been observed in Synechococcus strains (Grobbelaar et al. 1986, Sweeney \& Borgese 1989, Huang \& Chow 1990, Chow \& Tabita 1994). Members of this cyanobacterial genus are particularly abundant in natural phytoplankton communities of the open ocean and can be responsible for up to $80 \%$ of the water column primary production (Takahashi \& Hori 1984, Iturriaga \& Mitchell 1986). Similarly, members of the genus Prochlorococcus have recently been found to be as abundant (or more so) in open ocean environments (Chisholm et al. 1988, Campbell et al. 1994a).

We have presented preliminary evidence for diel regulation of $r b c L$ transcription in natural phytoplankton communities in the oligotrophic Gulf of Mexico (Pichard \& Paul 1991, Pichard et al. 1993). The present study was undertaken to expand on these initial findings and to extend these studies to determine the effect of continuous illumination or light:dark cycling on RubisCO regulation in phytoplankton.

\section{MATERIALS AND METHODS}

Sample collection. Surface seawater samples $(5 \mathrm{~m}$ depth) were collected at several stations in the oligotrophic Gulf of Mexico as shown in Fig. 1 Stn 1 $\left(26^{\circ} 58.3^{\prime} \mathrm{N}, 83^{\circ} 25^{\prime} \mathrm{W}\right)$ was the site of a Lagrangian diel study in which a patch of surface water was marked by a buoy and followed over $48 \mathrm{~h}$. Sampling was performed using a submersible pump to fill a $20 \mathrm{l}$ acid

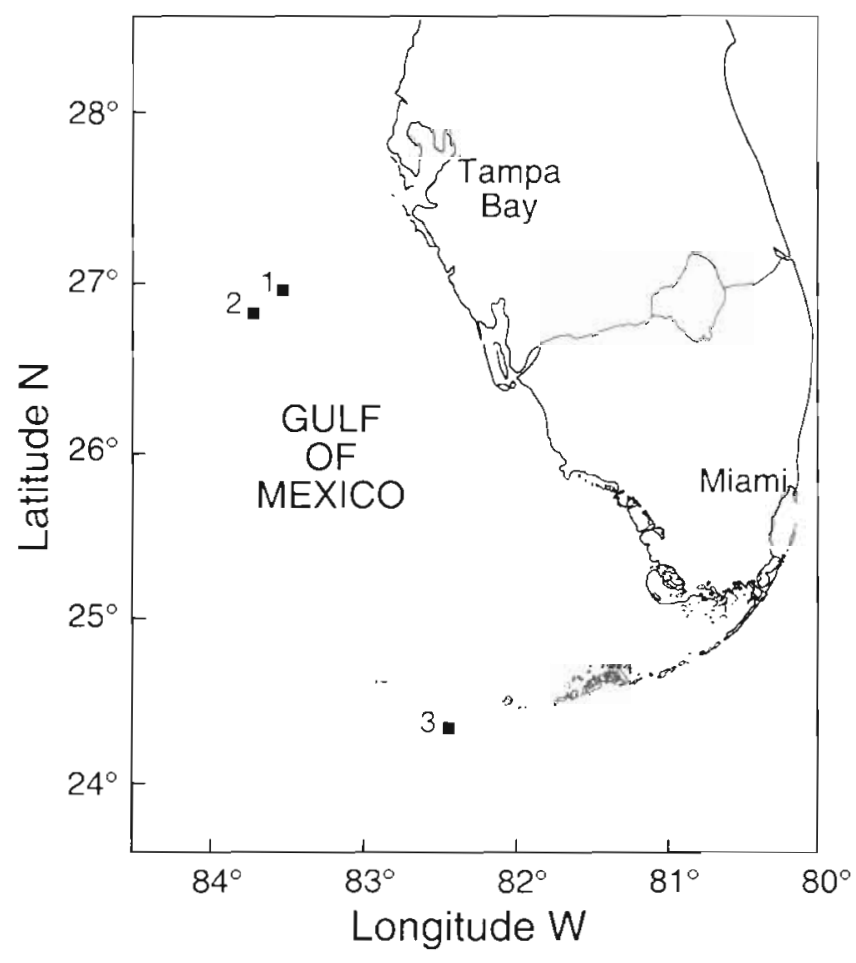

Fig. 1. Locations of stations sampled for diel studies. Stn 1 was the location of the $48 \mathrm{~h}$ Lagrangian study. Stn 2 was the location of the sampling site for the deck-top incubator (tank study) under natural illumination. Stn 3 was the location of surface water collected for the deck-top incubator study under artificial illumination schemes

washed polycarbonate carboy. At Stn $2\left(26^{\circ} 50^{\prime} \mathrm{N}\right.$, $83^{\circ} 49^{\prime}$ W) a $200 \mathrm{l}$ polyethylene tank was filled to $150 \mathrm{I}$ using a submersible pump lowered over the side of the ship. The tank was kept under natural irradiance reduced to $10 \%\left(-140 \mu \mathrm{E} \mathrm{m}^{-2} \mathrm{~s}^{-1}\right)$ surface irradiance by 2 layers of neutral density screening. The diel rhythm experiment was carried out at $\operatorname{Stn} 3\left(24^{\circ} 11^{\prime} \mathrm{N}\right.$, $82^{\circ} 30^{\prime} \mathrm{W}$ ). $150 \mathrm{l}$ of surface ( $5 \mathrm{~m}$ depth) seawater was collected using $30 \mathrm{l}$ niskin bottles and used to fill two $200 \mathrm{l}$ tanks covered with black plastic. Illumination was provided by submersible fluorescent lamps (NEC biolux $20 \mathrm{~W}$ fluorescent lights, $71 \mu \mathrm{E} \mathrm{m}^{-2} \mathrm{~s}^{-1}$, one tank being continuously illuminated and the other tank placed on a 12:12 h light:dark cycle. The temperature in tanks in all experiments was controlled to within $\pm 1^{\circ} \mathrm{C}$ using a refrigerated cooling recirculator (Fisher Scientific, Pittsburg, PA, USA) with coolant recirculated through $1 / 2$ inch $(1.27 \mathrm{~cm})$ diameter Tygon tubing $[1 / 16$ inch $(0.16 \mathrm{~cm})$ tube wall] in each tank. 10$)$ samples were collected from each tank by siphoning into 201 acid washed polycarbonate carboys.

rbcL mRNA analysis. Surface seawater and tanks were sampled at $4 \mathrm{~h}$ intervals and seawater collected for RNA and DNA analysis was first treated with diethylpyrocarbonate (DEPC; Sigma Chemical Co., St. 
Louis, MO, USA) to $0.1 \%$. Samples $(\sim 1000 \mathrm{ml})$, collected in duplicate, were filtered onto $25 \mathrm{~mm}, 0.45 \mu \mathrm{m}$ Durapore polyvinylidene difluoride membranes (Millipore, Inc., Bedford, MA, USAj and the mRNA extracted using guanidinium isothiocyanate and beadbeating as previously described (Pichard et al. 1993, Paul \& Pichard 1995). The purified RNA extracts were dotted onto Zetaprobe-GT charged nylon filters. RubisCO mRNA ( $r b c L$ ) was detected by probing under stringent conditions $\left(55^{\circ} \mathrm{C}\right.$ in $50 \%$ formamide) using ${ }^{35}$ S-labelled $r b c L$ antisense transcripts specific for cyanobacterial/chlorophyte RubisCO (Pichard et al. unpubl.) as described previously (Pichard \& Paul 1991, Pichard et al. 1993). The $r b c L$ probe was originally cloned from Synechococcus PCC6301. Dot blots were visualized using Kodak XAR2 X-ray film at $-40^{\circ} \mathrm{C}$ overnight. Radioactivity of detected $r b c L$ mRNA was quantified by beta-scanning (Ambis Systems Inc., San Diego, CA, USA) and compared to rbcL mRNA standard curves.

DNA analysis. Duplicate samples for RubisCO DNA. analysis were collected by filtration onto $25 \mathrm{~mm}$, $0.45 \mu \mathrm{m}$ Durapore membrane filters. Filters were placed in $2.2 \mathrm{ml}$ screw cap tubes containing $1.0 \mathrm{ml}$ of STE, pH 8.0 (Sambrook et al. 1989) and frozen at $-20^{\circ} \mathrm{C}$ for processing back in the laboratory. DNA was extracted by an adaptation of the Fuhrman et al. (1988) method, as previously described (Pichard \& Paul 1993). DNA samples were dot blotted as above and the rbcL DNA quantified by radioactive gene probing using antisense probes and comparison with DNA standard curves as for mRNA.

${ }^{14} \mathrm{C}$ carbon fixation. Rates of carbon fixation were measured by the ${ }^{14} \mathrm{C}-\mathrm{HCO}_{3}{ }^{-}$technique as in Strickland \& Parsons (1968) as modified by Carpenter \& Lively (1980). Samples were placed in sterile $500 \mathrm{ml}$ acid washed polycarbonate erlenmeyer flasks. Light and dark bottle incubations were used to determine light dependent rates of carbon fixation. Light bottle values were corrected by subtraction of dark bottle values. Radioactive bicarbonate was added to each light and dark flask at a final concentration of $0.5 \mu \mathrm{Ci} \mathrm{ml} \mathrm{m}^{-1}$. A zero time point sample $(100 \mathrm{ml})$ was taken by filtration through a $25 \mathrm{~mm}, 0.22 \mu \mathrm{m}$ GS filter (Millipore Corp.) and both light and dark bottles were incubated under constant cool-white fluorescent lights (average flux: $83 \mu \mathrm{E} \mathrm{m}^{-2} \mathrm{~s}^{-1}$; Sylvania-GTE). Duplicate $100 \mathrm{ml} \mathrm{sam-}$ ples were taken at the $2 \mathrm{~h}$ time point and the filters added to glass scintillation vials containing $0.5 \mathrm{ml}$ of $0.5 \mathrm{~N} \mathrm{HCl}$ and incubated overnight at room temperature. Sample radioactivity was determined by dissolving the filter in ethyl acetate, adding $10 \mathrm{ml}$ of Ecoscint A scintillation fluor (National Diagnostics) and liquid scintillation counting using a Delta 300 model 6891 liquid scintillation counting system (TM Analytic, Inc.).
Counting efficiency was determined by scintillation counting of a ${ }^{14} \mathrm{C}$ standard (Wang et al. 1975). Sample carbonate alkalinity and total carbon dioxide content were determined by titration with $0.01 \mathrm{~N} \mathrm{HCl}$ (Strickland \& Parsons 1968). Total carbon dioxide and incorporated ${ }^{14} \mathrm{C}$ were used to determine the rate of carbon fixation for each sample.

Autofluorescent and DAPI stained cell counts. Autofluorescent picoplankton (orange-yellow fluorescing and red fluorescing cells) were enumerated by the method of Vernet et al. (1990). Samples were filtered onto Irgalan black-stained, $25 \mathrm{~mm} 0.22 \mu \mathrm{m}$ Nuclepore filters in triplicate. The filters were then placed onto a microscope slide, $8 \mu \mathrm{l}$ of glycerol was placed between the filter and the cover slip and the filter stored in the dark and counted on board ship within several hours. Cells were enumerated using blue light excitation (450 nm) and $400 \times$ magnification with an Olympus $\mathrm{BH}-2$ epifluorescence microscope. For DAPI stained counts of total bacteria $20 \mathrm{ml}$ samples were collected and preserved with filtered formalin to await onshore processing. Cells were stained with DAPI and enumerated under UV light using epifluorescence microscopy (Paul 1982).

Chlorophyll a analysis. Samples for chl a were filtered in triplicate through Whatman GF/F filters and the filters stored at $-20^{\circ} \mathrm{C}$ until further analysis. The chl a was extracted in $100 \%$ methanol and quantified fluorometrically using a Turner Designs fluorometer (Holm-Hansen \& Riemann 1978).

Prochlorophyte culture and diel study. A Prochlorococcus sp. isolated from Stn ALOHA was grown in batch culture using K/2 PC media (Liu et al. 1995a) under blue light illumination at $10 \mu \mathrm{E} \mathrm{m} \mathrm{m}^{-2} \mathrm{~s}^{-1}$. Prochlorococcus cell concentrations were determined by flow cytometry (Liu et al. 1995a). Duplicate $2 \mathrm{ml}$ samples were collected by microcentrifugation and the cell pellet extracted in the same manner as for natural phytoplankton samples. rbcL mRNA detection and quantification was performed as with natural samples.

Statistical analysis. Regression analysis (Zar 1984) was used to determine sample rbcL mRNA and DNA concentrations from standard curves. Correlation analysis (Pearson correlation coefficient) was performed using Statgraphics Plus for Windows version 1.0 (Manuagistics, Inc., Rockville, MD, USA).

\section{RESULTS}

The results of sampling offshore stations in the Gulf of Mexico for diel variations in cyanobacterial/chlorophyte-like hybridizable rbcL mRNA, DNA and other parameters are shown in Figs. 2 to 5. A typical dot blot for extracted $r b c L$ mRNA from natural phytoplankton 


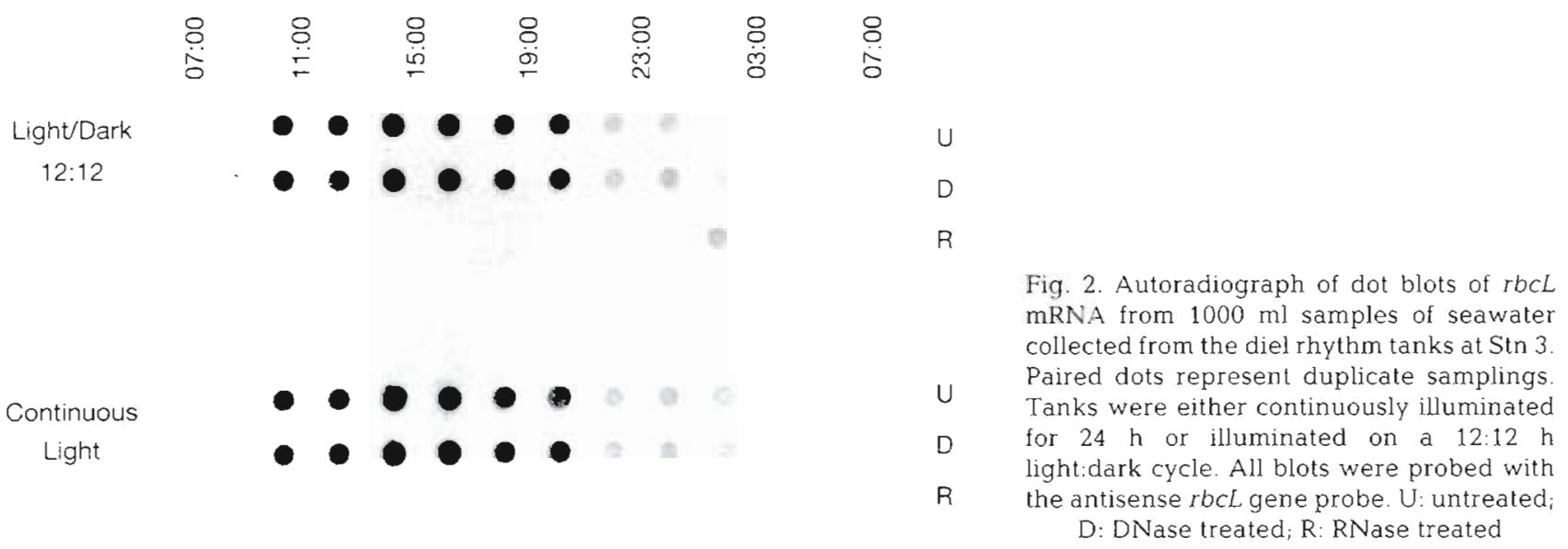

Table 1 Pearson correlation coefficients and significance level (p-value) between rates of carbon fixation and other mcasured parameters in the various diel experiments indicated. Significance is indicated by a p-value $<0.05$. BDC: bacterial direct counts; ND: not determined

\begin{tabular}{|lcccc|}
\hline Variable & Stn 1 & Stn 2 & Stn 3 Lt/Dk & Stn 3 Lt/Lt \\
\hline Temp & $0.267(0.400)$ & $-0.171(0.686)$ & $0.450(0.278)$ & $0.472(0.283)$ \\
Salinity & $0.419(0.175)$ & $0.073(0.864)$ & $0.0576(0.902)$ & $0.0005(0.999)$ \\
BDC & $0.0439(0.892)$ & $-0.236(0.574)$ & $-0.371(0.412)$ & $-0.035(0.940)$ \\
Synech. & $0.121(0.708)$ & $0.0342(0.936)$ & $0.268(0.562)$ & $0.440(0.323)$ \\
Red & ND & $-0.339(0.412)$ & $0.245(0.597)$ & $0.416(0.354)$ \\
Chl a & $-0.053(0.870)$ & $0.247(0.556)$ & $0.251(0.587)$ & $0.396(0.378)$ \\
mRNA & $0.778(0.003)$ & $0.775(0.024)$ & $0.578(0.114)$ & $0.520(0.182)$ \\
DNA & $0.424(0.169)$ & $-0.059(0.885)$ & $0.481(0.171)$ & $0.003(0.999)$ \\
\hline
\end{tabular}

populations appears in Fig. 2. At Stn 1 levels of rbcL mRNA varied from 0.121 to $22.24 \mathrm{ng} \mathrm{l}^{-1}$ with the highest levels found at 08:00 $\mathrm{h}$, the peak activity in carbon fixation (Fig. 3). Over this time period, variations in rbcl DNA, bacterial direct counts, chl a and Synechococcus counts were relatively small, and could not account for the peaks found in both carbon fixation and $r b c L$ mRNA. Although this station displayed the highest correlation coefficient between rbcL mRNA and carbon fixation (Table 1), one peak in carbon fixation had no corresponding peak in $r b c L$ mRNA. This can be seen in Fig. 3 at the
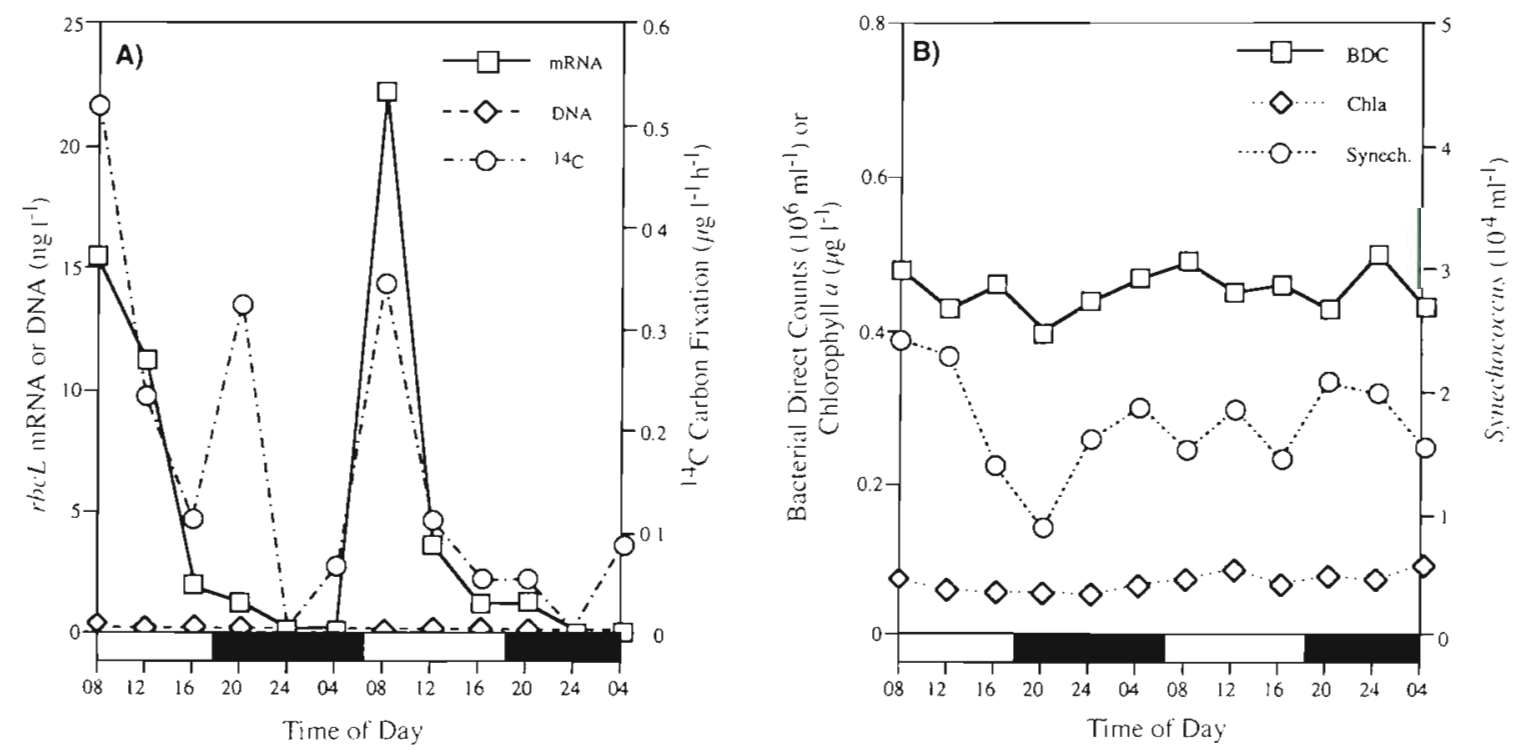

Fig. 3. Diel variations in $r b c L$ mRNA ${ }^{14} \mathrm{C}$ carbon fixation, and other parameters for the natural phytoplankton community from Stn 1. (A) Diel variations in activity parameters of $r b c L$ mRNA, carbon fixation, and RubisCO transcriptional template (rbcL DNA).

(B) Diel variations in biomass parameters of chl a concentration, autofluorescent cells (Synechococcus), and bacteria 
Fig. 4. Diel variations in rbcL mRNA, ${ }^{14} \mathrm{C}$ carbon fixation, and other parameters for the natural phytoplankton community in the tank study at Stn 2. (A) Diel variations in activity parameters of $r b c L$ mRNA and net carbon fixation. (B) Diel variations in rbcL DNA and chl a concentration. (C) Diel changes in rates of ${ }^{14} \mathrm{C}$ carbon fixation in light and dark bottle incubations throughout the study. (D) Diel variations in cells counts of bacteria and yellow-orange (Synechococcus) and red autofluorescing cells
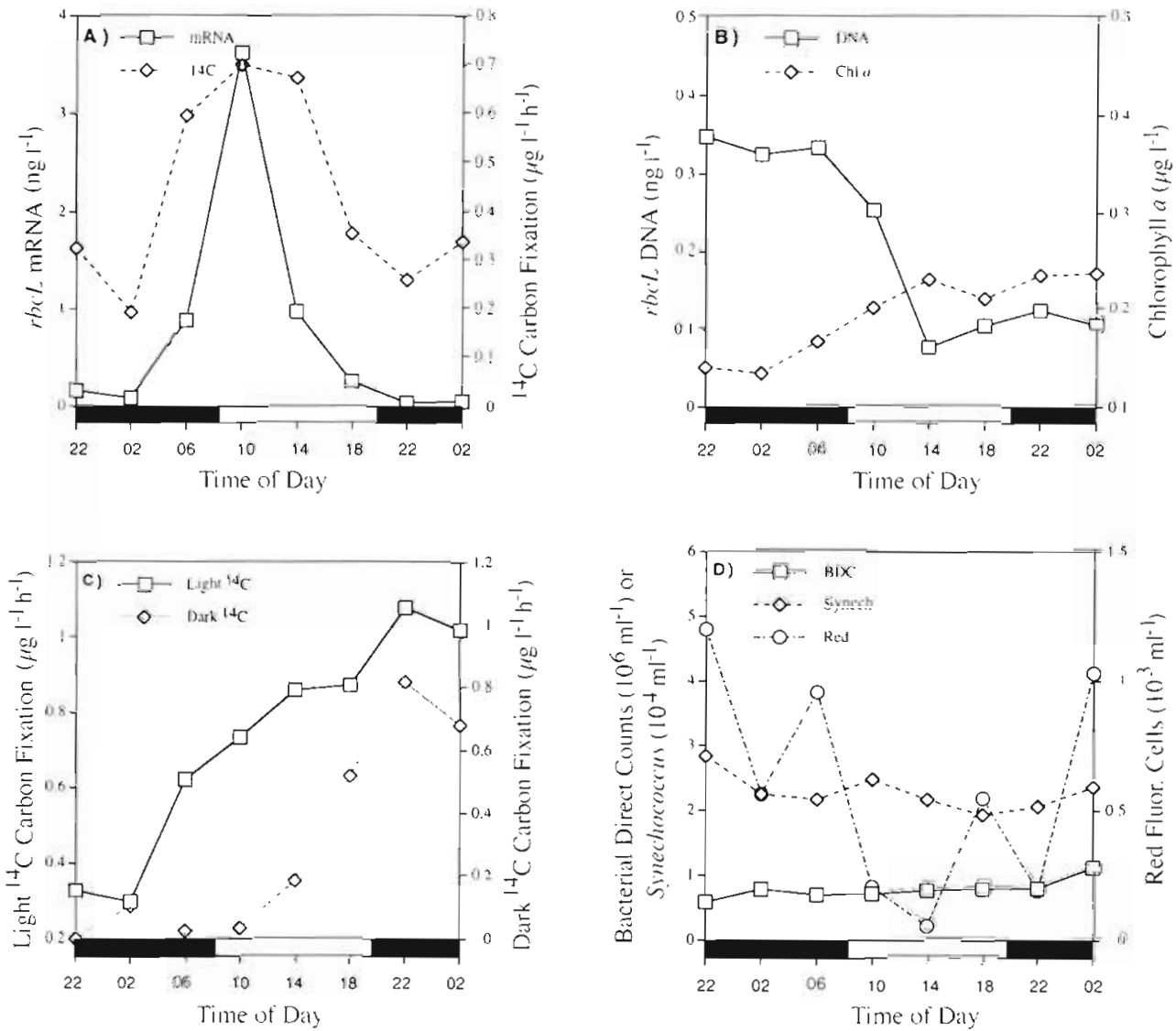

20:00 h time point, suggesting that another mechanism of regulation (perhaps activation of previously synthesized RubisCO) was occurring.

Diel patterns of $r b c L$ mRNA synthesis and carbon fixation were also observed in samples incubated in deck-top tanks under natural illumination (Fig. 4). In this study the highest correlation was seen between carbon fixation rates and $r b c L$ mRNA ( $r=0.775)$ with the peak activity in both parameters observed at 10:00 h. RubisCO large subunit mRNA ranged from 0.0444 to $3.626 \mathrm{ng} \mathrm{l}^{1}$ while net carbon fixation varied from 0.195 to $0.701 \mu g \mathrm{Cl}^{-1} \mathrm{~h}^{-1}$ (Fig. 4A) As the study progressed, rates of dark carbon fixation increased to levels comparable to light carbon fixation. Initially dark carbon fixation amounted to only $0.07 \%$ of carbon fixation rates in the light but increased to $76 \%$ of the light rate towards the end of the study (Fig. 4C). Levels of $\mathrm{rbcL}$ DNA decreased $\sim 3$-fold from the start of the study to the end while chl a nearly doubled rising from 0.141 to $0.238 \mathrm{\mu g} \mathrm{l}^{-1}$ (Fig. 4C). Synechococcus concentrations remained at a relatively constant level throughout the study (Fig. 4D). In contrast, red autofluorescing cells decreased by approximately 1 order of magnitude (from 1.20 to $0.055 \times 10^{3}$ cells $\mathrm{ml}^{-1}$ ) by $16 \mathrm{~h}$ into the study and then rising again over the next
$12 \mathrm{~h}$ to near initial levels. Bacterial direct counts in the tank nearly doubled from start to finish and displayed a correlation coefficient to dark carbon fixation rates of $\mathrm{r}=0.684$

Figs. $2 \& 5$ show the results of a diel study in natural populations in 2 deck-top tank incubators illuminated with artificial lighting, one on a $12: 12$ h light:dark cycle and the other continuously illuminated. Variations in rbcL mRNA (Fig 2) levels were nearly identical between the 2 illumination schemes, displaying highest values in the light and ranging from 0.129 to $22.17 \mathrm{ng} \mathrm{l}^{-1}$ Carbon fixation rates displayed peak activity either at or $4 \mathrm{~h}$ after the peak in $r b c L$ mRNA (Fig. 5A, D). In both tanks chl a decreased slightly from start to finish while rbcL DNA remained relatively the same at the start and end of the incubation (Fig. 5B, E). In both tanks, both red autofluorescent cell counts and Synechococcus counts decreased over the duration of the experiment. This demonstrates that changes were occurring in the composition of the microbial community over time in these enclosed water masses.

Fig. 6 displays the results of a study using the Prochlorococcus sp. culture maintained on a $12: 12$ h light:dark regimen or continuous illumination after 

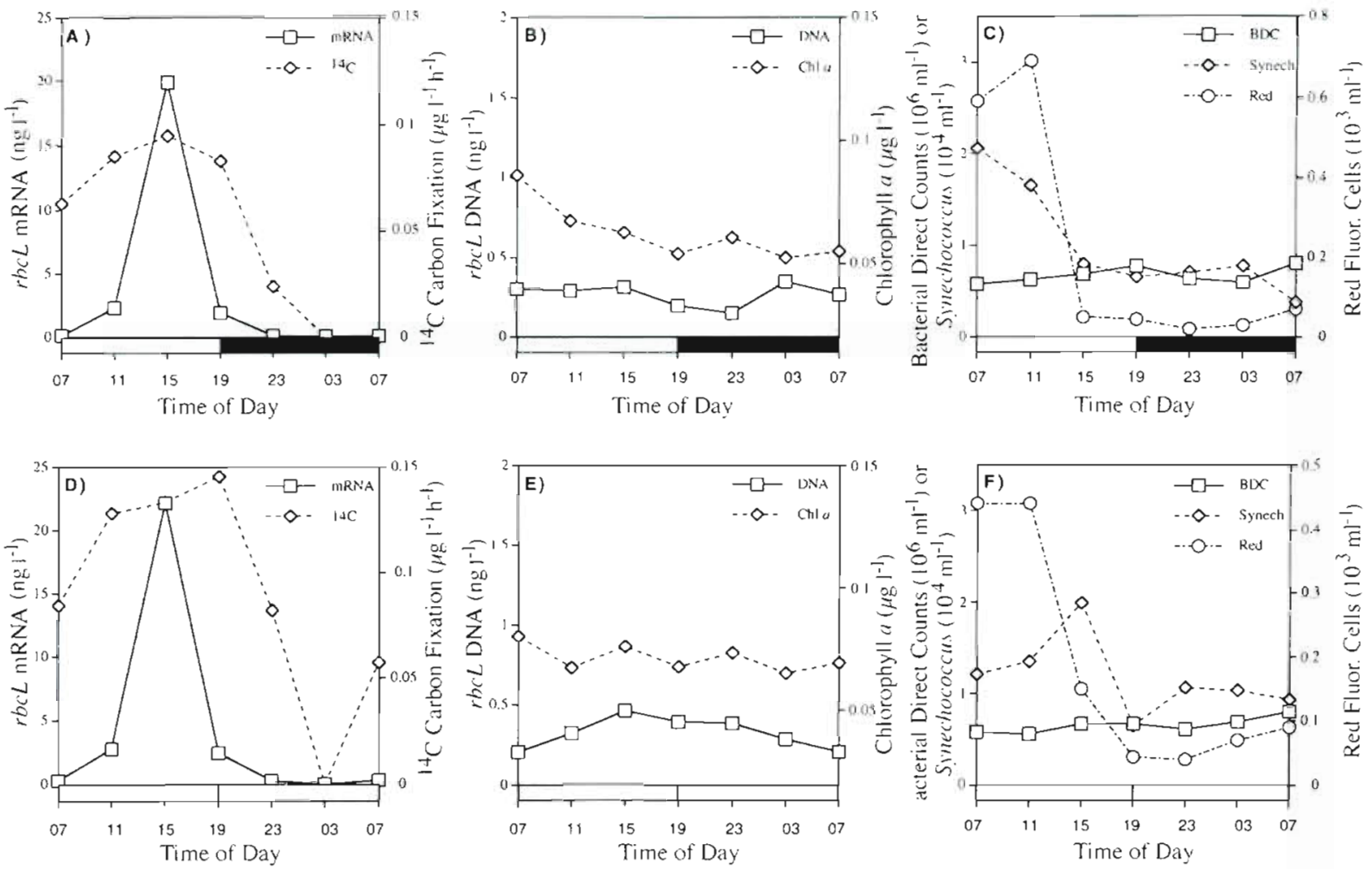

Fig. 5. Diel variations in $r b c L$ mRNA, ${ }^{14} \mathrm{C}$ carbon fixation, and other parameters for the natural phytoplankton community in the circadian rhythm study conducted at Stn 3. (A to C) Results for the 12:12 h light:dark illumunated tank; (D to F) results for the continuously illuminated tank. (A, D) Diel variations in activity parameters of $r b c L$ mRNA and carbon fixation in the light cycled and continuously illuminated tanks. (B, E) Diel variations in rbcL DNA and chl a concentrations for the same tanks. (C, F) Diel variations in cell counts of bacteria, yellow-orange (Synechococcus) and red autofluorescent cells for the same tanks

prior cultivation on a $12: 12 \mathrm{~h}$ light:dark illumination scheme. Under both illumination regimens, cells had elevated levels of $r b c L$ mRNA at the initiation of the light period. RubisCO large subunit mRNA ranged in concentration from $0.00550 \mathrm{fg} \mathrm{cell}^{-1}$ during the dark incubation and $0.107 \mathrm{fg} \mathrm{cell}^{-1}$ during the light period.
In all 3 studies variations in carbon fixation exhibited the highest Pearson correlation coefficients when correlated to $r b c L$ mRNA levels (range: $r=0.570$ to 0.778 ; Table 1). The lowest coefficient was exhibited in the rhythm study at Stn 3 in which the tank was continously illuminated and the highest coefficient was
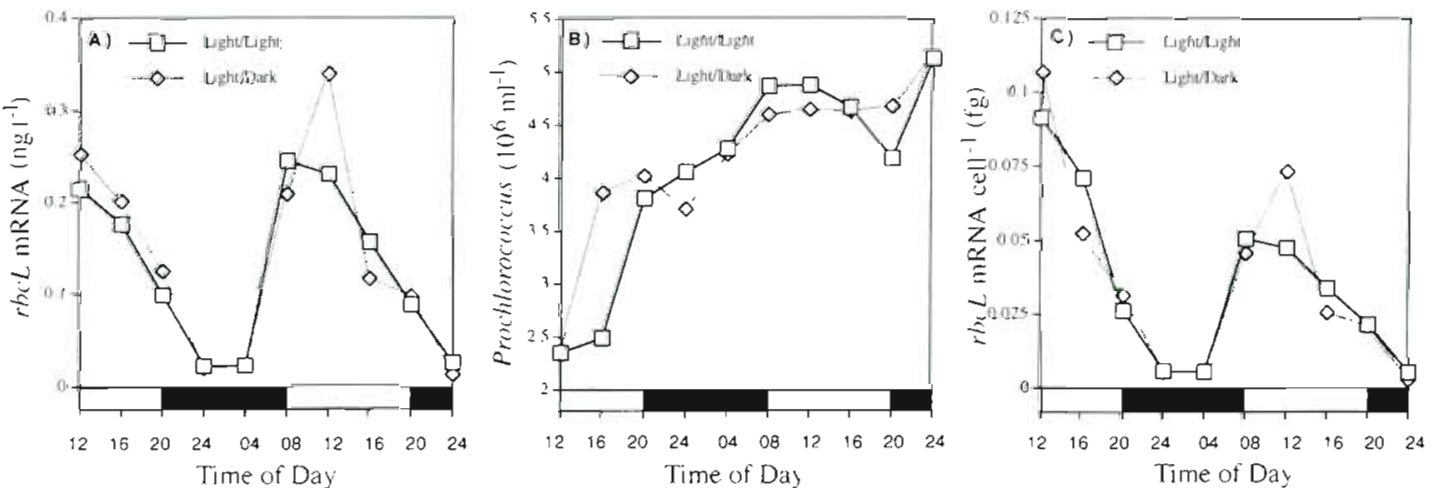

Fig. 6. Diel variations in rbcL mRNA and flow cytometric determıned Prochlorococcus cell counts for a culture divided and placed under cycled lllumination $(12: 12 \mathrm{~h}$ light:dark) and under continuous illumination. (A) Variation in $r b c L$ m.RNA as a function of time. (B) Variation in cell concentration as a function of time. (C) Variation in rbcL mRNA per cell as a function of time 
found in the Lagrangian study at Stn 1. In these studies no other measured variable displayed a higher level of correlation than that between carbon fixation and rbcL mRNA. These results demonstrate a coupling between transcription of $r b c L$ mRNA and rates of carbon fixation.

\section{DISCUSSION}

A consistent pattern of diel transcriptional regulation of cyanobacterial/chlorophyte-like rbcL has been observed in phytoplankton populations in a Lagrangian study, in phytoplankton populations enclosed in deck-top incubators, and in an oceanic picoplankter in culture. In all instances, transcription of $r b c L$ occurred early in the light phase, and diminished at the end of the light phase and into the dark phase. Concentrations of $r b c L$ transcript positively correlated with the rate of photosynthetic carbon fixation, when measured.

Elucidating regulatory mechanisms in natural populations of phytoplankton is technically difficult and the approaches taken here are not without limitations. The Lagrangian approach has the advantage of no containment ('bottle') artifacts. However, because no tracer was used to track the water mass except a dragued buoy, we are not certain of the homogeneity of the water mass sampled. Additionally, no compensation has been made for potential vertical mixing, advection, or vertical migration of phytoplankton communities. The deck-top incubator overcomes the problems of water mass homogeneity, but has artifacts associated with containment. For example, the increase in dark fixation rates in both tank experiments and the decrease in autofluorescent cell counts in the second tank experiment indicate that population changes were occurring. Despite these differences in approach and methodological drawbacks, both indicated a diel pattern in RubisCO transcription.

The diel variations in $r b c L$ transcription appear to be rhythmic in nature and tied to light cues. Variations in $r b c L$ mRNA have been demonstrated for both natural phytoplankton communities (Pichard et al. 1993) and for a variety of clonal isolates of various phytoplankton taxa (Reynolds et al. 1993, Chow \& Tabita 1994). In many of these cases it appears that transcriptional activity at the level of the $r b c L$ gene or RubisCO operon is responsible for regulating carbon fixation capabilities in such organisms.

We do not know if all components of the phytoplankton regulate their RubisCOs as demonstrated here for cyanobacterial/chlorophytic members. While it is not expected that the Synechococcus rbcL gene probe employed here will detect all RubisCO types present in surface water communities, this probe has been demonstrated to hybridize with DNA from various marine Synechococcus, Prochlorococcus, and prasinophytes (Pichard et al. unpubl.). It is not expected to detect variations in $r b c L$ mRNA for the chromophyte algae, for dinoflagellates, or for some Prochlorococcus $\mathrm{sp}$. as these organisms possess either evolutionary variants of the type I RubisCO or type II RubisCOs (Newman \& Cattolico 1990, Morse et al. 1995, Shimada et al. 1995, Tabita 1995)

There are a myriad of regulatory mechanisms known for RubisCO in various photoautotrophs, including activation and inhibition by substrates and metabolites, activation by RubisCO activase, and regulation of assembly by chaperonins, to name a few (Tabita 1988, 1994, 1995). Some evidence for regulation of rbcL by modulating gene dose has been observed in Chlamydomonas reinhardtii (Hosler et al. 1989). In the diel studies presented here $r b c L$ gene dose appears to have a limited role in regulating $r b c L$ gene expression as much of the variation is within rbcL mRNA. However, small variations in the template for transcription can result in large changes of transcripts as in C. reinhardii.

Other enzymes such as phosphoribulokinase and carbonic anhydrase play potential roles by controlling cellular levels of ribulose bisphosphate (RuBP) and $\mathrm{CO}_{2}$. respectively (Tabita 1988, 1994, 1995, Badger \& Price 1994). Therefore, enzymes that are responsible for controlling the delivery of substrate to the RubisCO enzyme may also have a regulatory role in the Calvin Cycle. Photosynthetic electron flow between PSII and PSI has also been shown to be important in the cellular accumulation of $r b c L$ transcripts in Synechocystis sp (Mohamed \& Jansson 1991), as well as in several terrestrial plants, and thus may be part of the signaling between the light and dark reactions in photosynthesis. Whether $r b c L$ transcript levels in natural phytoplankton communities are dependent upon the same type of mechanism is an open question. It is also not known whether, in the case of type I RubisCO, small subunit (rbcS) transcripts are modulated in the same manner.

Beta-carboxylating enzymes, such as phosphoenolpyruvate carboxylase (PEPCase), phosphoenolpyruvate carboxykinase, and pyruvate carboxylase, may also be involved in the carbon metabolism of phytoplankton as well as the anaplerotic replenishment of TCA intermediates in heterotrophic microbes. The maximum yield that PEPCase can provide to carbon metabolism is $25 \%$ and in most natural cases is more on the order of $12.7 \%$ or less (Mortain-Bertrand et al. 1988).

One of the most significant findings in this work is the evidence for circadian rhythms in transcription of $r b c L$ in natural phytoplankton communities and a 
Prochlorococcus strain. Circadian rhythms, once thought to occur only in eukaryotic organisms (Sweeney 1983), are now being recognized in prokaryotes such as cyanobacteria. Rhythms in expression of a number of genes in several cyanobacteria are shown to occur at the transcriptional level. Transcriptional control of both photosynthetic $(r b c L)$ and nitrogen fixing (nifH) activities has been demonstrated to occur in a reciprocal manner in Synechococcus sp. RF-1 (Chow \& Tabita 1994) and to be rhythmic in nature (nifH) under light:dark and continuous light conditions (Huang \& Chow 1990). Other genes, such as psbA, purF, gInA, $\operatorname{rrn} A$, and $d n a K$, have been demonstrated to exhibit circadian rhythms in their expression in Synechococcus sp. PCC7942 and Synechocystis sp. PCC6803 (Aoki et al. 1995, Kondo et al. 1995, Liu et al. 1995b). The major taxa comprising oligotrophic phytoplankton communities are recognized as Synechococcus sp., Prochlorococcus sp., and chromophytic members of the ultraphytoplankton such as prymnesiophytes, chrysophytes, diatoms, and others (Campbell \& Vaulot 1993, Campbell et al. 1994b, Li 1995). Therefore, it might be expected that gene expression would display some form of rhythmicity in communities dominated by such members. Whether this rhythmic expression is truly circadian awaits further tests of phase resetting and temperature compensation.

The data presented here suggest that these natural communities of oligotrophic phytoplankton utilize the mechanism of regulation of $r b c L$ mRNA levels as one control on carbon fixation. Whether such variations are a result of increases and decreases of transcription rates, variations in mRNA turnover rates, or a combination of the 2 remains to be investigated. $r b c L$ mRNA may be controlled by a clock-set rhythmic mechanism that controls the cellular levels of $r b c L$ mRNA, and therefore carbon fixation, using a variety of the above processes. Evidence is presented here that establishes that rhythms in rbcL mRNA levels are present in both natural phytoplankton communities and in Prochlorococcus sp. Whether other members of the autotrophic picoplankton community also display rhythms in $r b c L$ mRNA is currently being investigated. In any case, it is clear that molecular tools have revealed the importance of events occurring at the level of transcription in regulating the physiologically and globally important process of carbon fixation in the oceans.

Acknowledgements. This research was supported by National Science Foundation grants OCE9216937 and 9218517 and DOE grants DE-FG05-93ER6199 and LE-FG0293ER61700 to J.1 I.P. and F.R.T., respectively. S.L.P. was supported b; a USGS Coastal Science Fellowship and a Knight Oceanorraphic Research Fellowship from the USF Dept. of Marine Science. Technical assistance was provided by H. G. Williams, J. B. Willıams, C. A. Kellogg, and S. Jiang.

\section{LITERATURE CITED}

Aoki S, Kondo T, Ishiura M (1995) Circadian expression of the dnaK gene in the cyanobacterium Synechocystis sp. strain PCC6803. J Bacteriol 177:5606-5611

Badger MR, Price GD (1994) The role of carbonic anhydrase in photosynthesis. A Rev Plant Physiol Plant Mol Biol 45: 369-392

Campbell L, Nolla HA, Vaulot D (1994a) The importance of Prochlorococcus to community structure in the central North Pacific Ocean. Limnol Oceanogr 39:954--961

Campbell L, Shapiro LP. Haugen E (1994b) Immunochemical characterization of eukaryotic ultraplankton from the Atlantic and Pacific Oceans. J Plankton Res 16:35-51

Campbell L, Vaulot D (1993) Photosynthet.c p.coplankton community structure in the subtropical North Pacific Ocean near Hawaii (Station ALOHA). Deep Sea Res 40: 2043-2060

Carpenter DJ, Lively JS (1980) Review of estimates of algal growth using "C-tracer techniques. In: Falkowski PG (ed) Primary productivity in the sea. Plenum Press, New York, p 161-178

Chisholm SW, Olson RJ, Zettler ER, Goeriche R, Waterbury JB, Welschmeyer NA (1988) A novel free-living prochlorophyte abundant in the oceanic euphotic zone. Nature 334 $340-343$

Chow TJ, Tabita FR (1994) Reciprocal light-dark transcriptional control of nif and $r b c$ expression and lightdependent posttranslational control of nutrogenase activity in Synechococcus sp. strain RF-1 J Bacteriol 176 6281-6285

Doty MS, Oguri M (1957) Evidence for a photosynthetıc darly periodicity. Limnol Oceanogr 2:37-40

Falkowski PG (1994) The role of phytoplankton photosynthesis in global blogeochemical cycles. Photosynth Res 39 $235-258$

Fuhrman JA, Comeau DE, Hagström $\AA$, Chan AM (1988) Extraction from natural planktonic microorganisms of DNA suitable for molecular biological studies. Appl Environ Microbiol 54:1426-1429

Glover HE, Morris I (1979) Photosynthetic carboxylating enzymes in marine phytoplankton. Limnol Oceanogr 24: $510-519$

Grobbelaar N, Huang TC, Lin HY, Chow TJ (1986) 1)initrogen-fixing endogenous rhythm in Synechococcus RF-1 FEMS Microbiol Lett 37:173-177

Holm-Hansen O, Riemann B (1978) Chlorophyll a determination: improvements in methodology. Oikos 30:438-447

Hosler JP, Wurtz EA, Harris EH, Gillham NW, Boynton JE (1989) Relationship between gene dosage and gene expression in the chloroplast of Chlamydomonas reinhardtii. Plant Physiol 91:648-655

Huang TC, Chow TJ (1990) Characterization of the rhythmic nutrogen-fixing activity of Synechococcus $\mathrm{sp}$. RF-1 at the transcriptional level. Curr Microbiol 20:23-26

Iturriaga R, Mitchell BG (1986) Chroococcoid cyanobacteria: a significant component in the food web dynamics of the open ocean. Mar Ecol Prog Ser 28:291-297

Kondo T, Tsinoremas NF, Golden SS, John CH, Katsuna S, Ishiura M (1995) Circadian clock mutants of cyanobacteria. Science 266:1233-1236

Legendre L, Demers S, Garside C, Haugen EM, Phinney DA, Shapiro LP, Therriault JC, Yentsch CM (1988) Circadian photosynthetic activity of natural marine phytoplankton isolated in a tank. J Plankton Res 10:1-6

Li WKW (1995) Composition of ultraphytoplankton in the central North Atlantic. Mar Ecol Prog Ser 1.22:1-8 
Liu H, Campbell L, Landry MR (1995a) Growth and mortality rates in Prochlorococcus and Synechococcus measured with a selective inhibitor technique. Mar Ecol Prog Ser 116:277-287

Liu Y, Tsinormas NF, Johnson CH, Lebedeva NV, Golden SS, Ishiura M, Kondo T (1995b) Circadian orchestration of gene expression in cyanobacteria. Genes \& Dev 9: $1469-1478$

Mohamed A, Jansson C (1991) Photosynthetic electron transport controls degradation but not production of $p s b A$ transcripts in the cyanobacterium Synechocystis 6803. Plant Mol Biol 16:891-897

Morse D. Saloıs P, Markovic P, Hastings JW (1995) A nuclearencoded form IJ RubisCO in dinoflagellates. Science 268: $1622-1624$

Mortain-Bertrand A, Descolas-Gros C, Jupin H (1988) Pathway of dark inorganic carbon fixation in 2 species of diatoms: influence of light regime and regulator factors on diel variations. J Plankton Res 10:199-217

Newman SM, Cattolico RA (1990) Ribulose bisphosphate carboxylase in algae: synthesis, enzymology, and evolution. Photosynth Res 26:69-85

Orellana MV, Perry MJ (1992) An immunoprobe to measure RubisCO concentrations and maximal photosynthetic rates of individual phytoplankton cells. Limnol Oceanogr $37: 478-490$

Paul JH (1982) The use of Hoechst dyes 33258 and 33342 for enumeration of attached and planktonic bacteria. Appl Environ Microbiol 43:939-944

Paul JH, Pichard SL (1995) Extraction of DNA and RNA from aquatic environments. In: Trevors JD, Van Elsas JD (eds) Nucleic acids in the environment. Springer-Verlag, Berlin, p $153-177$

Pichard SL, Frischer ME, Paul JH (1993) Ribulose bisphosphate carboxylase gene expression in subtropical marine phytoplankton populations. Mar Ecol Prog Ser 101:55-65

Pichard SL, Paul JH (1991) Detection of gene expression in genetically engineercd microorganisms and natural phytoplankton populations in the marine environment by mRNA analysis. Appl Environ Microbiol 51:1721-1727

Pichard SL, Paul JH (1993) Gene expression per gene dose: a specific measure of gene expression in aquatic microorganisms. Appl Environ Microbiol 59:451-457

This article was presented by S. Y. Newell /Senior Editorial Advisor), Sapelo Island, Georgia, USA
Reynolds AE, McConaughy BL, Cattolico RA (1993) Chloroplast genes of the marine alga Heterosigma carterae are transcriptionally regulated during a light/dark cycle. Mol Mar Biol Biotechnol 2:121-128

Sambrook J, Fritsch EF, Maniatis T (1989) Molecular cloning: a laboratory manual, 2nd edn. Cold Spring Harbor Laboratory Press, Cold Spring Harbor, NY

Shimada A, Kanai S, Maruyama T (1995) Partial sequence of ribulose-1,5-bisphosphate carboxylase/oxygenase and the phylogeny of Prochloron and Prochlorococcus (Prochlorales). J Mol Evol 40:671-677

Strickland JDH, Parsons TR (1968) A manual of seawater analysis, 2nd edn. Bull Fish Res Bd Can 125:1-311

Sweeny BM (1983) Circadian time-keeping in eukaryotic cells, models and hypotheses. Prog Phycol Res 2:189-225

Sweeny BM, Borgese MB (1989) A circadian rhythm in cell division in a prokaryote, the cyanobacterium Synechococcus WH7803. J Phycol 25:183-186

Tabita FR (1988) Molecular and cellular regulation of autotrophic carbon dioxide fixation in microorganisms. Microbiol Rev 52:155-189

Tabita FR (1994) The biochemistry and molecular regulation of carbon dioxide fixation in cyanobacteria. In: Bryant DA (ed) The molecular biology of cyanobacteria. Kluwer Academic Publishers, Dordrecht, p 299-329

Tabita FR (1995) The biochemistry and metabolic regulation of carbon metabolism and $\mathrm{CO}_{2}$ fixation in purple bacteria. In: Blankenship RE, Madigan MT, Bauer CE (eds) Anoxygenic photosynthetic bacteria. Kluwer Academic Publishers, Dordrecht, p 885-914

Takahashi M, Hori T (1984) Abundance of picophytoplankton in the subsurface maximum layer in subtropical and tropical waters. Mar Biol 79:177-186

Vernet M, Mitchell BG, Holm-Hansen O (1990) Adaptation of Synechococcus in situ determined by variability in intracellular phycoerythrin-543 at a coastal station off the Southern California coast, USA. Mar Ecol Prog Ser 63: 9-16

Wang DH, Willis DL, Loveland WD (1975) Radiotracer methodology in the biological, environmental, and physical sciences. Prentice-Hall, Englewood Cliffs, NJ

Zar JH (1984) Biostatistical analysis, 2nd edn. Prentice-Hall, Englewood Cliffs, NJ

Manuscript first received: January 2, 1996

Revised version accepted: April 4, 1996 